\author{
Abstracta Iranica \\ Abstracta Iranica Revue bibliographique pour le domaine irano-aryen \\ Volume 32-33 | 2013 \\ Comptes rendus des publications de 2009-2010
}

\title{
Florence Jullien. Réseaux monastiques en Mésopotamie. À propos du pacte de Bar Qaiți
}

\section{Rédaction}

\section{(2) OpenEdition}

1 Journals

\section{Édition électronique}

URL : http://journals.openedition.org/abstractairanica/40847

DOI : 10.4000/abstractairanica.40847

ISSN : 1961-960X

Éditeur :

CNRS (UMR 7528 Mondes iraniens et indiens), Éditions de l'IFRI

\section{Édition imprimée}

Date de publication : 1 décembre 2013

ISSN : 0240-8910

\section{Référence électronique}

Rédaction, «Florence Jullien. Réseaux monastiques en Mésopotamie. À propos du pacte de Bar Qaiți », Abstracta Iranica [En ligne], Volume 32-33 | 2013, document 332, mis en ligne le 01 juillet 2016, consulté le 26 septembre 2020. URL : http://journals.openedition.org/abstractairanica/40847 ; DOI : https://doi.org/10.4000/abstractairanica.40847

Ce document a été généré automatiquement le 26 septembre 2020.

Tous droits réservés 


\title{
Florence Jullien. Réseaux monastiques en Mésopotamie. À propos du pacte de Bar Qaiți
}

\author{
Rédaction
}

\section{RÉFÉRENCE}

Florence Jullien. « Réseaux monastiques en Mésopotamie. À propos du pacte de Bar Qaiți ». Oriens christianus 93, 2009, p. 28-40.

1 Les fondations monastiques des disciples du « Père des moines de l'Orient », Abraham d'Izla ( $\mathrm{VI}^{\mathrm{e}} \mathrm{s}$.), se sont souvent structurées en réseaux d'alliance, formant autant de relais d'influence de ce nouveau courant réformateur. Cette étude portera sur l'un de ces réseaux, dans la région du Singar. Le groupement d'anciens proches d'Abraham dans cette aire géographique nous permet de réévaluer et de comprendre les motivations ayant conduit à l'instauration du traité de Bar Qaiți fédérant plusieurs couvents syro-orientaux de la région en 598. Le fonctionnement de ce maillage monastique s'effectue en fait en relais de l'action dogmatique et disciplinaire menée par les moines réformés du Grand monastère, et conduite, à l'échelle de tout l'empire sassanide, par Babaï le Grand. 


\section{AUTEURS}

\section{RÉDACTION}

Directeur de la revue et secrétariat (Paris) 